\title{
OPTIMALISASI RUANG TERBUKA HIJAU (RTH) MUSHOLLAH DARUSSALAM DESA LEMAHBANGDEWO ROGOJAMPI KABUPATEN BANYUWANGI BERBASIS GREEN AREA (SEBAGAI AREA RESAPAN) GUNA MENINGKATKAN KENYAMANAN
}

\section{OPTIMIZATION OF GREEN OPENED SPACE (RTH) OF MUSHOLLAH DARUSSALAM, LEMAHBANGDEWO VILLAGE ROGOJAMPI BANYUWANGI DISTRICT, BASED ON GREEN AREA (AS A SORPTION AREA) TO INCREASE COMFORTNESS}

\author{
Mirza Ghulam Rifqi ${ }^{\# 1}$, Herman Yuliandoko ${ }^{\# \# 2}$, M. Shofi'ul Amin ${ }^{\# 3}$, Syarifah Khairunnisa ${ }^{\# 4}$, \\ Hendri Kuswoyo ${ }^{\# 5}$, Irawan Saputra ${ }^{\# 6}$, Farra Anindita ${ }^{\# 7}$, Barirotul Azizah ${ }^{\# 8}$ \\ \# Jurusan Teknik Sipil Politeknik Negeri Banyuwangi \\ \#\#urusan Teknik Informatika, Politeknik Negeri Banyuwangi \\ Jalan Raya Jember km.13 Labanasem Kabat Banyuwangi
}

${ }^{1}$ mirza@poliwangi.ac.id

\begin{abstract}
Abstrak
Mushollah Darussalam merupakan mushollah fasilitas sosial (Fasos) yang disediakan oleh developer guna menunjang aktivitas ibadah bagi warga muslim di Perumahan Citra Garden. Mushollah Darussalam memiliki halaman yang cukup luas namun menimbulkan kesan kurang luas, akibat dari belum tertatanya halaman Mushollah secara optimal. Kondisi yang kotor, rimbun dan tidak tertata mengurangi keindahan dan kenyamanan masyarakat desa Lemahbangdewo dalam beraktivitas dan beribadah. Metode : Kegiatan ini merupakan upayaupaya guna mengoptimalisasi RTNH Mushollah Darussalam dengan konsep green area. Halaman mushollah ditata dan dilapisi material pengerasan agar bersih, luas dan rapi namun tetap mengoptimalkan fungsinya sebagai area resapan. Pada kegiatan ini dilakukan beberapa tahapan dengan alur pelaksanaannya yang meliputi survey lokasi dan pengukuran lokasi, koordinasi hasil survey dan penyusunan draf gambar rencana, penyusunan desain RTNH, koordinasi dan penyampaian hasil penyusunan gambar rencana dan penerapan gambar rencana serta penerapan teknologi tepat guna. Hasil : Kegiatan ini berhasil memberikan wawasan dan pengetahuan mengenai pentingnya penataan area terbuka. Kegiatan ini berhasil mengubah wajah halaman Mushollah Darussalam yang awalnya kotor, rimbun dan tidak tertata menjadi rapi, bersih, menimbulkan kesan luas dan asri. Penataan landscape dikombinasikan dengan taman dan material berpori sehingga area resapan masih berfungsi sebagaimana mestinya. Dengan dilakukannya penataan landscape halaman mushollah, masyarakat bisa melakukan aktivitas luar ruangan di halaman mushollah Darussalam.
\end{abstract}

Kata Kunci : Mushollah Darussalam, green area, landscape, material berpori.

Abstract

Mushollah Darussalam is a social facility provided by the developer to support religious activities for Muslims in Citra Garden Residence. Mushollah Darussalam has a fairly large yard but gives the impression of narrow field, effect of the not yet optimally arranged of Mushollah yard. Dirty, lush and disorganized conditions reduce the beauty and comfort of Lemahbangdewo villagers in their activities and worship. Method: This activity is efforts to optimize the Mushollah Darussalam landscape with the concept of green area. The mushollah yard is arranged and covered with pavement material to be clean, spacious and neat but still optimizes its function as a catchment area. In this activity carried out several stages with the implementation flow among others : survey location and site measurements, coordination of survey results and drafting of drawing plan, drafting of landscape designs, coordination and delivery of the results of the preparation of drawings plan and implementation of drawings plan and application of appropriate technology.Results: This activities gave insights and knowledge about the importance of arrangement open areas. This activity succeeded in changing the façade of Mushollah Darussalam yard which was originally dirty, lush and unorganized into a neat, clean, creating a broad and beautiful impression. Landscape arrangement is combined with garden and porous material so that the catchment area still functions as it should. By organizing the landscape of the mushollah courtyard, the community can conduct outdoor activities in the Darussalam mushollah yard.

Keywords: Mushollah Darussalam, green area, landscape, porous material. 


\section{PENDAHULUAN}

Dusun Satriyan merupakan salah satu dusun di desa Lemahbangdewo dan berada pada sisi selatan dan sisi utara kantor desa Lemahbangdewo. Di desa Lemahbangdewo terdapat perumahan Citra Garden yang berdiri sejak tahun 2011 dan saat ini dihuni oleh 99 Kepala Keluarga dengan beraneka profesi. Perumahan Citra Garden merupakan perumahan yang pertama kali berdiri di desa Lemahbangdewo. [4]. Perumahan Citra Garden memiliki Fasilitas Sosial (Fasos) yang disediakan oleh developer, dimana fasos tersebut digunakan sebagai tempat ibadah, yaitu Mushollah Darussalam.

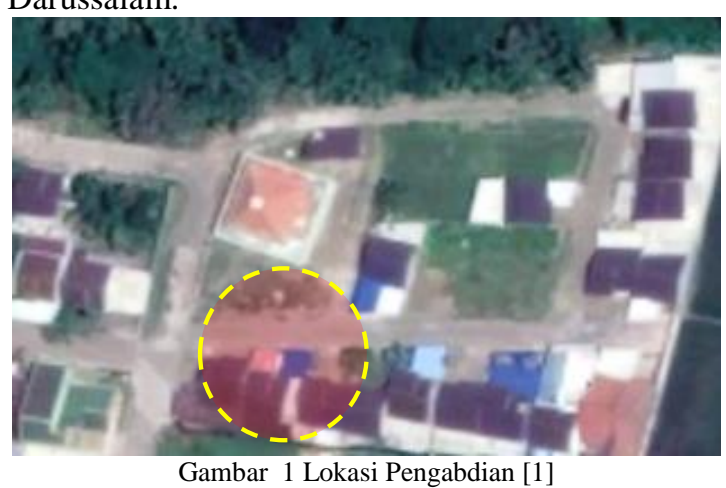

Mushollah Darussalam berada disisi timur perumahan Citra Garden dengan sungai Prengsengan disisi utara mushollah. Lokasi Mushollah Darussalam ditunjukkan pada Gambar 1 .

Mushollah Darussalam dibangun pada tahun 2015 dengan dana swadaya masyarakat Dusun Satriyan Desa Lemahbangdewo. Mushollah memiliki luas bangunan $132 \mathrm{~m} 2$ dengan luas lahan 429 m2. Halaman atau lahan disekitar bangunan mushollah belum benar-benar diperhatikan. Dengan kemampuan, pengetahuan dan dana seadanya, mengakibatkan kualitas bangunan dan landscape Ruang Terbuka Hijau (RTH) di Mushollah Darussalam belum tertata dengan optimal. Hal ini bisa dilihat pada Gambar 2.

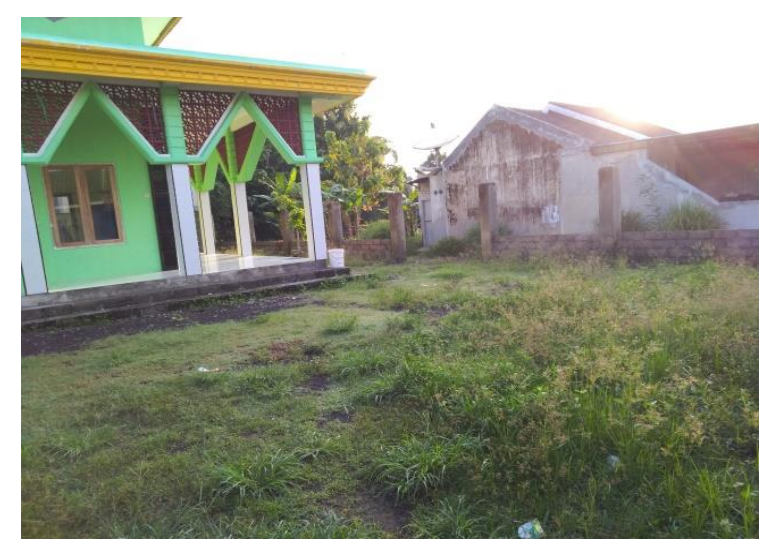

Gambar 2 Kondisi eksisting halaman Mushollah Darussalam

Belum tertatanya landscape dan RTNH Mushollah Darussalam mengakibatkan beberapa permasalahan. Kontur tanah yang tidak rata, munculnya genangan air setiap selesai turun hujan, munculnya tanaman liar dan tidak bisa tumbuhnya tanaman peneduh menjadi permasalahan yang sering muncul pada RTH Mushollah Darussalam.

Salah satu solusi penataan RTH dan landscape mushollah adalah dengan pemasangan paving. Paving banyak digunakan untuk pengerasanpengerasanpengerasan jalan kompleks perumahan, memperindah taman, halaman rumah, pengerasanpengerasan areal parkir, areal perkantoran, halaman sekolah, serta fasilitas umum lainnya [3]. Aplikasi paving pada halaman mushollah Darussalam merubah fungsi RTH menjadi RTNH berbasis green area.

Untuk mengurangi genangan dan memperbesar resapan air tanah, penataan landscape dikombinasikan menggunakan paving berongga. Dengan perkembangan teknologi sekarang ini, dilakukan usaha untuk meningkatkan kinerja paving menjadi lebih efektif dan efisien sebagai bahan pengerasan jalan yaitu dengan cara membuat paving berongga yang memungkinkan aliran permukaan untuk infiltrasi ke dalam tanah. [2]. Dengan aplikasi paving berongga, diharapkan RTNH bisa berfungsi sebagai RTH seperti sediakala.

\section{TARGET DAN LUARAN}

Sasaran pengabdian masyarakat adalah warga Dusun Satriyan, Desa Lemahbangdewo Kecamatan Rogojampi Kabupaten Banyuwangi khususnya jamaah Mushollah Darussalam.

Target pengabdian ini adalah penerapan iptek dengan mengoptimalkan RTH Mushollah Darussalam menjadi RTNH berbasis green area, sehingga RTNH 
masih bisa berfungsi sebagai area resapan air tanah. Solusi tersebut didapatkan dari penelitian sebelumnya yang sudah pernah dilakukan.

Luaran dari kegiatan ini adalah Penerapan Teknologi Tepat Guna sebagai implementasi penelitian sebelumnya. Lokasi pengabdian akan terbentuk tatanan dan konsep sebagai RTNH berbasis green area. Tampilan RTNH menjadi indah dan asri serta mempengaruhi daya tarik warga dalam melaksanakan kegiatan keagamaan. Warga sekitar lokasi mampu melakukan aktifitas ibadah tanpa gangguan meskipun pada saat musim penghujan. Produk luaran pada kegiatan pengabdian antara lain:

1. Publikasi pada media masa cetak lokal,

2. Publikasi pada jurnal,

3. Penerapan Teknologi Tepat Guna sebagai implementasi penelitian sebelumnya.

\section{METODE PELAKSANAAN}

Pada kegiatan ini dilakukan beberapa tahapan dan alur pelaksanaannya yang meliputi survey lokasi dan pengukuran lokasi, koordinasi hasil survey dan penyusunan draf rencana desain, penyusunan desain RTNH, koordinasi dan penyampaian hasil penyusunan gambar rencana dan penerapan gambar rencana serta penerapan teknologi tepat guna.

\section{1) Survey}

Dalam tahapan ini dilakukan beberapa survey lokasi dan identifikasi permasalahan, antara lain:

a. Permasalahan yang dihadapi,

b. Situasi lokasi dan pengukuran halaman mushollah.

2) Koordinasi hasil survey dan penyusunan draf rencana desain

Dalam tahapan ini dilakukan koordinasi dengan takmir dan perwakilan warga untuk menyampaikan hasil survey dan penyampaian rencana desain.

3) Penyusunan Desain RTNH

Hasil survey dan koordinasi dengan takmir dituangkan dalam gambar rencana. Penyusunan draf gambar rencana bertujuan untuk memberikan gambaran kepada takmir dan warga mengenai rencana pelaksanaan kegiatan. Masukan, saran dan permintaan takmir dan perwakilan warga diakomodir untuk selanjutnya menjadi bahan pertimbangan dalam melakukan penyusunan gambar rencana.

4) Koordinasi dan penyampaian hasil penyusunan gambar rencana

Gambar rencana final disampaikan dalam rapat koordinasi dengan takmir mushollah
Darussalam dan perwakilan warga. Gambar rencana harus sudah memuat posisi perletakan material pengerasan, jenis material pengerasan, posisi taman dan jenis tanaman yang ditanam pada taman. Finalisasi gambar rencana akan menjadi acuan dalam pelaksanaan kegiatan.

5) Penerapan Gambar Rencana dan Penerapan Teknologi Tepat Guna (TTG)

Bersama dengan takmir dan warga memperbaiki dan mewujudkan gambar rencana sesuai dengan desain dan konsep green area. Konsep TTG mengaplikasikan paving konvensional, paving berongga, penataan landscape dan taman. Mutu paving yang digunakan adalah paving dengan mutu D yang digunakan untuk taman dan penggunaan yang lain [5].

\section{HASIL DAN PEMBAHASAN}

Pelaksanaan kegiatan dilakukan dalam beberapa kegiatan, antara lain survey dan koordinasi dengan takmir dan perwakilan warga. Dalam koordinasi tersebut, perwakilan warga diwakili oleh pengurus lingkungan. Survey dan koordinasi dilakukan untuk mendapatkan ketepatan target pelaksanaan dan kebutuhan warga dan takmir. Koordinasi dengan perwakilan warga dan takmir ditunjukkan pada Gambar 3. Hasil koordinasi dengan perwakilan warga dan takmir dijadikan dasar dalam menyusun rencana kerja dan draf gambar rencana.

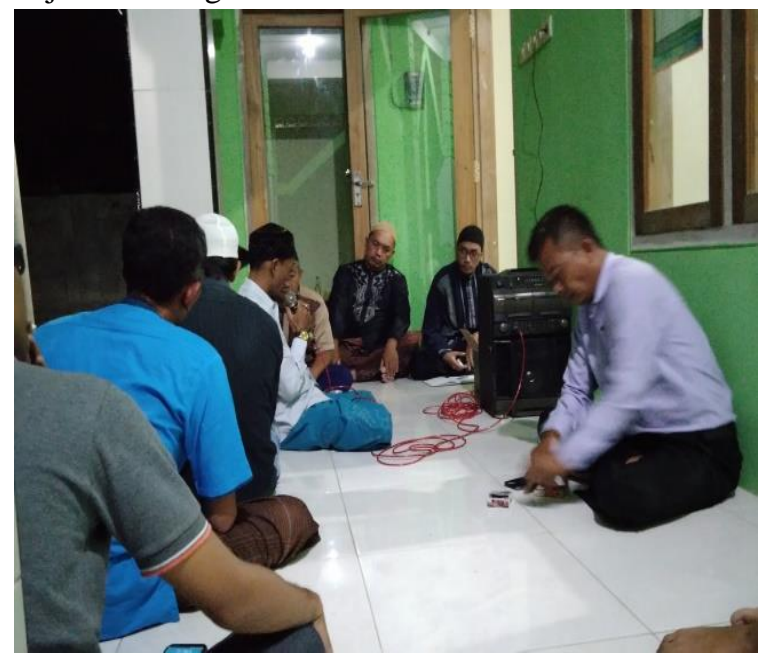

Gambar 3 Rapat koordinasi dengan takmir dan perwakilan warga

Penyusunan gambar rencana disampaikan dalam rapat koordinasi berikutnya. Dalam rapat tersebut membahas target kegiatan dan rencana penataan landscape halaman mushollah Darussalam. Kegiatan tersebut disajikan pada Gambar 4. 


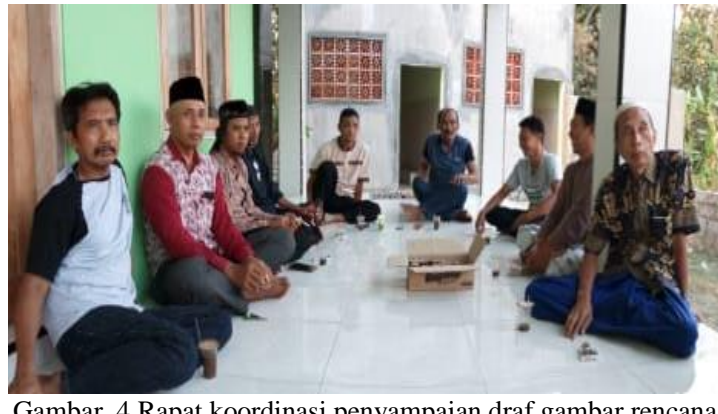

Gambar 4 Rapat koordinasi penyampaian draf gambar rencana

Setelah melakukan rapat koordinasi kegiatan selanjutnya adalah dengan melakukan finalisasi gambar kerja. Gambar kerja disusun sebagai dasar pelaksanaan kegiatan. Gambar kerja mengakomodir target pelaksanaan kegiatan dan masukan-masukan dari takmir dan perwakilan warga. Gambar kerja yang sudah final ditunjukkan pada Gambar 5.

Setelah gambar kerja final disusun, kegiatan selanjutnya adalah dengan melakukan persiapan pelaksanaan kegiatan. Persiapan tersebut antara lain pembersihan lokasi bersama warga, penataan landscape halaman mushollah, pengadaan material pengerasan, pemasangan material pengerasan, pengadaan komponen landscape dan taman sebagai fungsi green area.

Pembersihan lokasi bersama warga dilaksanakan secara gotong royong pada hari minggu. Proses pembersihan adalah dengan membersihkan halaman mushollah dari rumput dan tanaman liar lainnya. Kegiatan tersebut ditunjukkan pada Gambar 6.

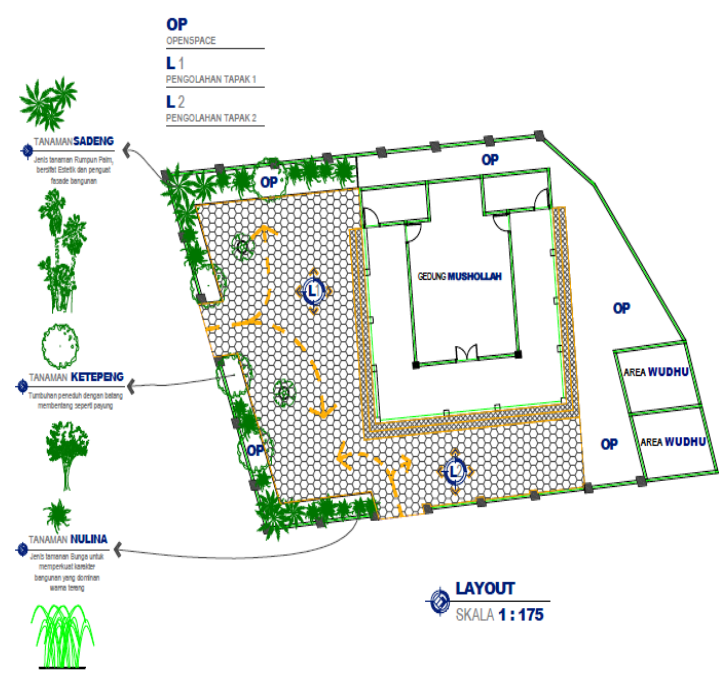

Gambar 5 Rencana pelaksanaan penataan landscape halaman mushollah Darussalam

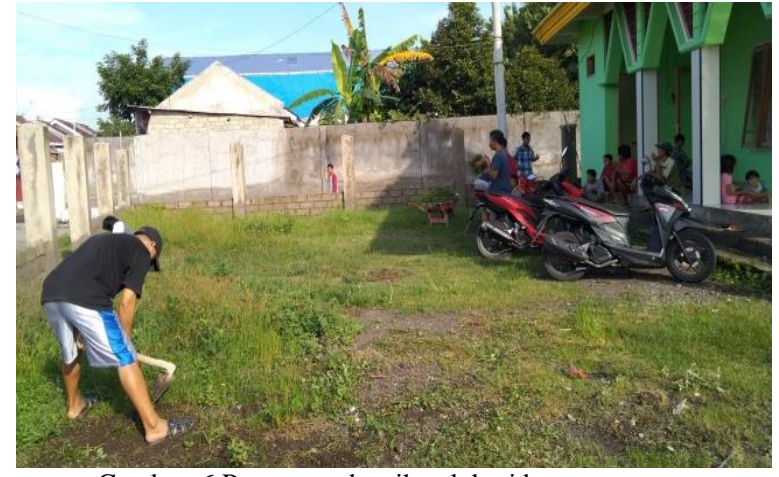

Gambar 6 Proses pembersihan lokasi bersama warga

Pada minggu berikutnya, warga secara bersama-sama melakukan penataan landscape di lokasi. Penataan landscape adalah dengan melakukan perataan kontur tanah dan mengurug halaman dengan pasir sebagai dasar pemasangan paving. Kegiatan tersebut ditunjukkan pada Gambar 7.

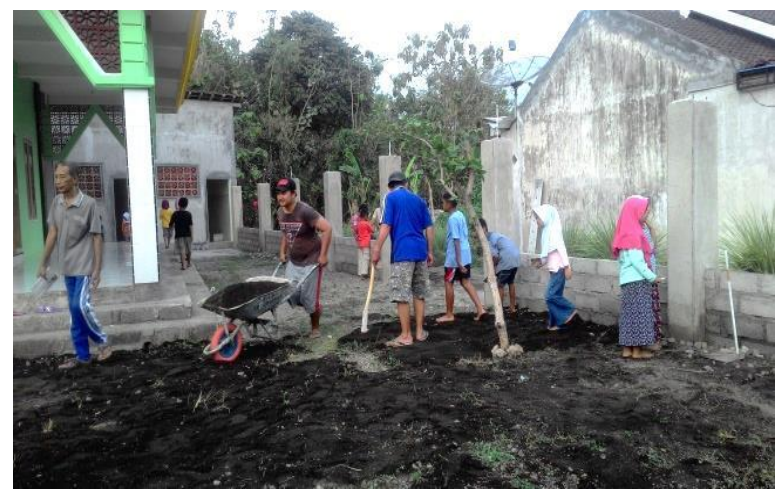

Gambar 7 Proses penataan landscape di lokasi bersama warga

Setelah proses penataan landscape, kegiatan berikutnya adalah pengadaan material pengerasan. Material pengerasan yang digunakan adalah paving dengan mutu D, yaitu paving dengan peruntukkan taman dan penggunaan lain, seperti pejalan kaki, jogging track dan lain sebagainya. Material pengerasan digunakan untuk melapisi halaman mushollah agar elevasi dan kontur halaman menjadi rata dan bersih. Proses pengadaan material pengerasan ditunjukkan pada Gambar 8 .

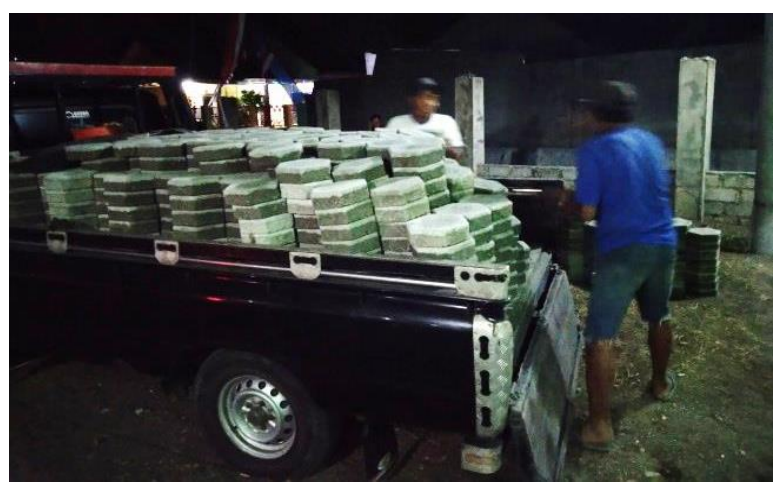

Gambar 8 Proses pengiriman material pengerasan 
Untuk memastikan kerataan dan kesikuan pada saat pemasangan paving, perlu dilakukan pengukuran dan pemeriksaan level elevasi (uitzet) halaman menggunakan prinsip sifat air. Jika elevasi dan kesikuan halaman sudah bisa dipastikan, selanjutnya adalah dengan melakukan pemasangan patok. Kegiatan ini ditunjukkan pada Gambar 9.

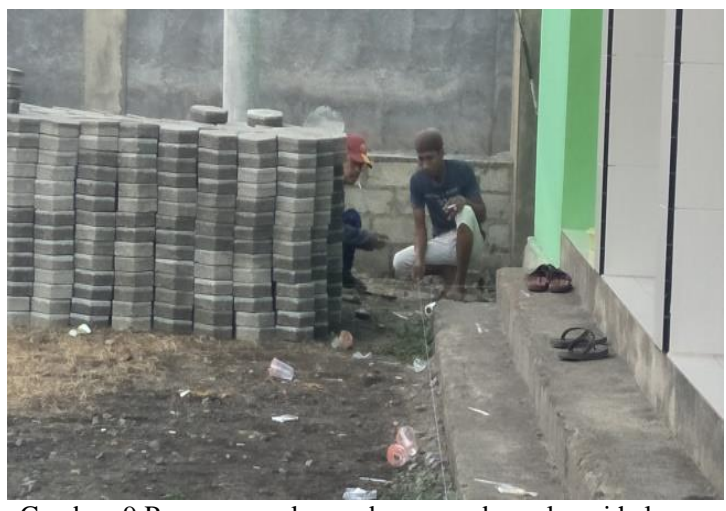

Gambar 9 Proses pengukuran dan penandaan elevasi halaman mushollah

Setelah dilakukan pemasangan patok, selanjutnya urugan pasir bawah paving dihampar dengan mengikuti elevasi yang sudah ditentukan. Batas pemasangan dan ketinggian urugan pasir mengikuti batas yang telah ditandai pada patok. Setelah urugan pasir dihampar, urugan pasir dipadatkan secara sederhana lalu paving dihampar diatas urugan pasir. Aktivitas tersebut ditunjukkan pada Gambar 10.

Selama proses pelaksanaan kegiatan, pengawasan dilakukan secara simultan. Pengawasan tersebut dilakukan guna memastikan ketepatan pemasangan paving sesuai dengan rencana landscape yang telah disusun. Proses pengawasan pemasangan paving ditunjukkan pada Gambar 11.

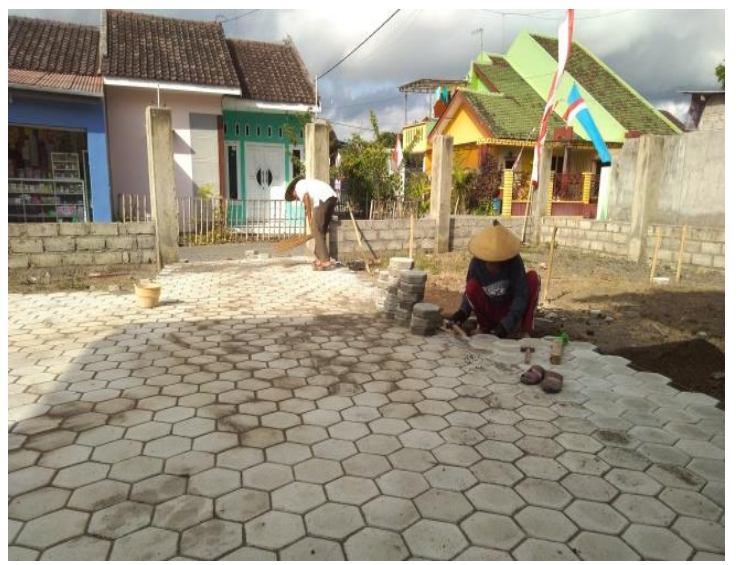

Gambar 10 Proses pemasangan paving halaman mushollah

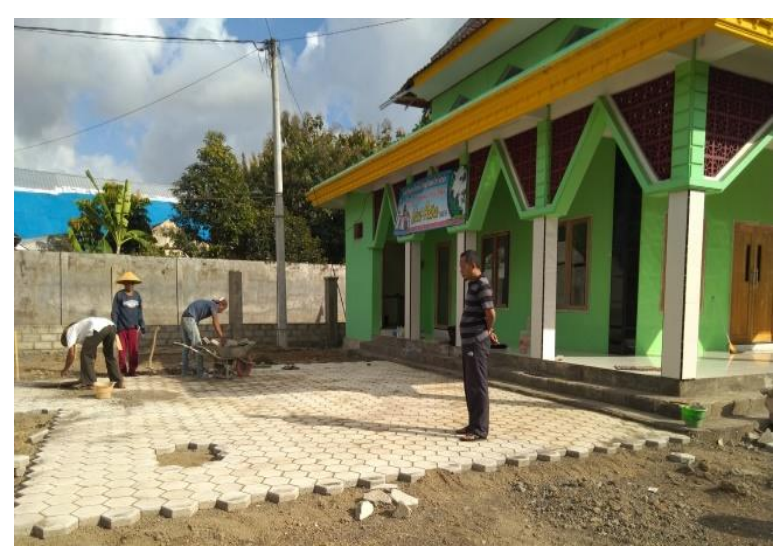

Gambar 11 Proses pemeriksaan dan pengawasan pemasangan paving

Setelah pemasangan paving selesai dilaksanakan, selanjutnya adalah proses pembuatan dan penataan taman. Selain digunakan untuk mempercantik penampilan landscape, taman difungsikan juga sebagai area penyerapan air hujan. Proses pembuatan taman ditunjukkan pada Error! Reference source not found..

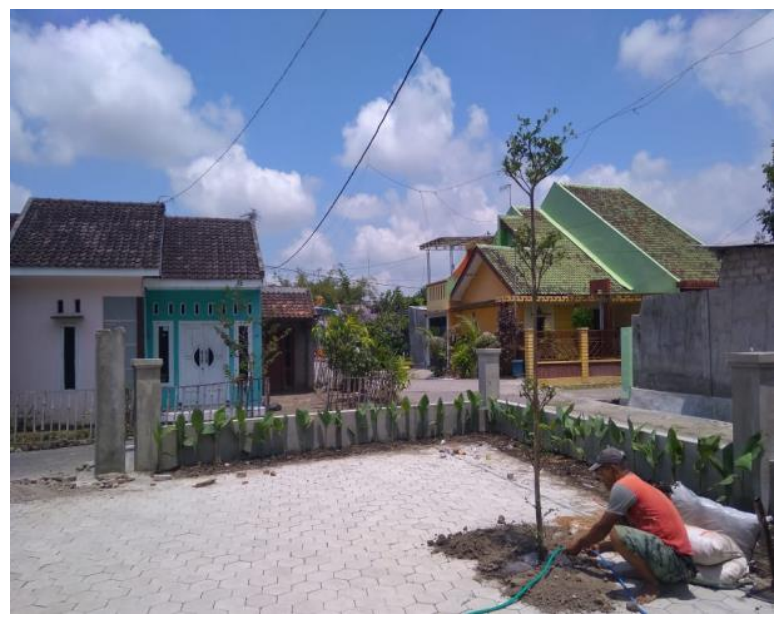

Gambar 12 Proses pembuatan taman

Taman yang telah dibentuk terdiri dari tanaman vertikal yaitu tanaman berupa tanaman hias kana merah dan rumput mutiara yang membantu proses penyerapan air hujan. Sedangkan di area resapan lainnya ditanam pohon ketepeng yang difungsikan sebagai tanaman peneduh dan berfungsi membantu penyerapan air hujan. Perubahan area RTNH Mushollah Darussalam memberikan kesan luas dan asri, sehingga meningkatkan kenyamanan jamaah Mushollah Darussalam dalam melaksanakan aktivitas ibadah. Hasil akhir penataan taman, landscape dan RTNH Mushollah Darussalam ditunjukkan pada Gambar 13 dan Gambar 14. 


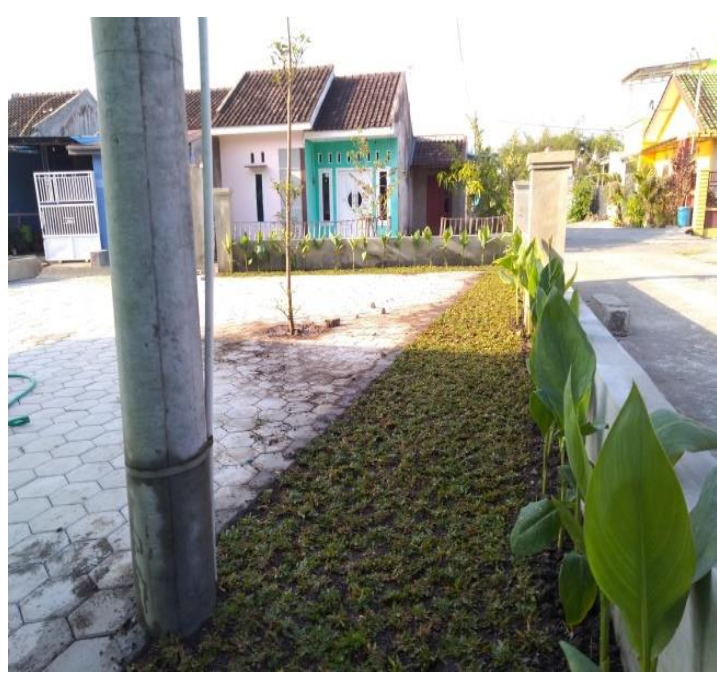

Gambar 13 Hasil akhir penataan taman

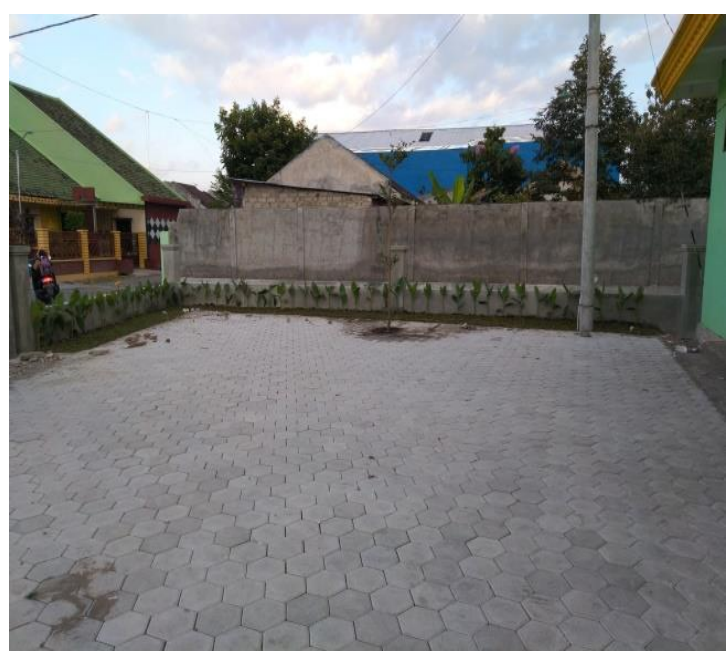

Gambar 14 Hasil akhir penataan landscape dan RTNH Mushollah Darussalam

\section{KESIMPULAN}

Optimalisasi ruang Terbuka Hijau (RTH) Mushollah Darussalam Desa Lemahbang Dewo Rogojampi Kabupaten Banyuwangi Berbasis green area (sebagai area resapan) guna meningkatkan kenyamanan menghasilkan kesimpulan, antara lain :

1. Bertambahnya wawasan dan pengetahuan masyarakat mengenai pentingnya penataan area terbuka.

2. Kegiatan pengabdian ini berhasil mengubah wajah halaman Mushollah Darussalam yang awalnya kotor, rimbun dan tidak tertata menjadi rapi, bersih, menimbulkan kesan luas dan asri.

3. Selain melapisi halaman mushollah dengan material pengerasan, namun fungsi area resapan masih bisa berfungsi. Hal terjadi karena penataan landscape dikombinasikan dengan taman dan material berpori.
4. Dengan dilakukannya penataan landscape halaman mushollah, aktivitas-aktivitas masyarakat Desa Lemahbangdewo menjadi lebih bervariasi. Permainan anak-anak dan aktivitas ibadah bisa dilakukan di halaman mushollah. Penataan landscape tidak mengganggu fungsi area resapan, namun tetap memberikan efek positif bagi lingkungan.

\section{UCAPAN TERIMAKASIH}

Kegiatan Pengabdian Kepada Masyarakat ini terlaksana karena dukungan dari beberapa pihak. Ucapan terima kasih disampaikan kepada Pusat Penelitian dan Pengabdian kepada Masyarakat (P3M) Politeknik Negeri Banyuwangi, Kepala Desa Lemahbangdewo dan Takmir Mushollah Darussalam sebagai mitra dalam PKM ini serta seluruh civitas akademika Politeknik Negeri Banyuwangi yang telah turut membantu kegiatan Pengabdian Kepada Masyarakat ini.

\section{DAFTAR PUSTAKA}

[1] https://www.google.com/maps/. (2019). Retrieved April 21, 2019 ,

from https://www.google.com/maps/place/Perum+Citra+Garden+R esidence/

[2] Rifqi, M. G., Amin, M., \& Lesmana, Y. I. (2018). Karakteristik Paving Berongga Menggunakan Material Batu Kali Bulat Berbasis Ramah Lingkungan. Potensi, 2 No. 1, 2932.

[3] Rifqi, Mirza Ghulam; Amin, M. Shofi'ul; Sandi, Ariyanto Enes; Suryani, Erna. (2016). Pelatihan Teknologi Konstruksi Paving Dalam Mengembangkan Kawasan Desa Labanasem. J-Dinamika, 1 No. 2, 125-129.

[4] Rifqi, Mirza Ghulam; Yuliandoko, Herman; Amin, M. Shofi'ul. (2019). PKM Desa Lemahbangdewo Rogojampi Kabupaten Banyuwangi Normalisasi Saluran Air Hujan dan Grey Water (Air Kotor Rumah Tangga) guna Meningkatkan Kenyamanan dan Kesehatan Warga Perumahan Citra Garden. J-Dinamika, 4 No. 1, 67-71.

[5] SNI. (1996). SNI 03-0691-1996 Bata Beton (Paving Block). Jakarta: Badan Standarisasi Nasional. 